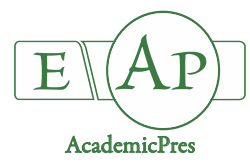

\title{
Histocytological Study of Somatic Embryogenesis in the Tree Cinnamomum camphora L. (Lauraceae)
}

\author{
Ruyue JING ${ }^{1}$, Peilan WANG ${ }^{1}$, Zhen $\mathrm{HUANG}^{2}$, Zhihui LI ${ }^{1 *}$ \\ ${ }^{1}$ Central South Forestry University of Science and Technology, Changsha 410004, P. R. China; lzh1957@126.com ("corresponding author) \\ ${ }^{2}$ Sichuan Academy of Forestry Sciences, Chengdu 610000, P. R. China
}

\begin{abstract}
Histocytological studies were conducted on primary, secondary, and malformed embryos produced during somatic embryogenesis of Cinnamomum camphora L. to better understand its development. Exploring its callus types and structures provided a theoretical basis for clarifying the mechanism of somatic embryogenesis, which may shed light on the mechanism of zygotic embryogenesis. We used immature zygotic embryos as explants to induce somatic embryos, forming many embryogenic calli that differentiated into mature somatic embryos. Our results showed that somatic embryogenesis of C. camphora was similar to that of zygotic embryos. We have been dedifferentiated four types of callus. Compared with non-embryogenic cells, embryogenic cells had a closer arrangement, larger nucleus, thicker cytoplasm, more starch granules and easier to stain into black. Somatic embryogenesis had two pathways: direct (predominate) and indirect (rare). Embryogenic cells of C. camphora could have either an internal or external origin, the latter being primary, for which occurrence sites include epidermis and nearepidermis (little internally). Mostly arising from single cells, C. camphora follows two developmental pathways: single-cell equal as opposed to unequal, wherein both divide to form multi-cell proembryos. However, multicellular origins can occasionally occur and feature physiological isolation during somatic embryo development. This development has four embryo stages: globular, heart-shaped, torpedo, and cotyledon, with procambium cells apparent in globular embryos and late cotyledons forming "Y-shaped" vascular bundles. Secondary embryos were present in all stages, directly occurring on primary embryo's germ and radicle end surfaces. We conclude that secondary and primary embryos of $C$. camphora undergo similar developmental processes. At the same time, conjoined cotyledon embryos and morphological abnormal embryos were found, with an internal origin more likely to generate abnormal embryos.
\end{abstract}

Keywords: Cinnamomum camphora L.; histocytology; malformed embryos; primary somatic embryos; secondary somatic embryos; somatic embryogenesis

\section{Introduction}

The tree Cinnamomum camphora L., belonging to the order Laurales (Lauraceae), is a representative species of subtropical evergreen broad-leaved forest and provides dense canopy shade (Zhang, 2009). In China, it is a precious native tree found at the south of the Yangtze River and is a national second-class wild protected plant species (Zou et al., 2009). This species may serve not only as a landscape plant but also as a natural spice resource for aromatic camphor (Guo et al., 2016). In the medicinal field, this plant may be used to treat muscular strains and rheumatic materials (Grieve, 1979; Babu et al., 2003).

In the late 20th century, somatic embryos (SE), an important type of plant tissue culture, began to be widely used in the asexual reproduction of woody plants (Tautorus, 1991; Zimmerman, 1993). SE promised much potential for the efficient and economical mass production of clonal planting stock (Becwar, 1993), while also serving as an ideal system for synthetic seed technology (Reddy et al., 2012), genetic engineering (Henderson and Walter, 2006), and plant cell biology studies (Fowke et al., 1995). SE has since become a viable method not only for mass propagation, but also a stepping stone for developing other manufacturing biotechnology for new products in forestry (Klimaszewska et al., 2011; Maruyama and Hosoi, 2018). Not surprisingly, studies of somatic embryogenesis of more tree species are occurring, including that of broad-leaved (Capuana, 1997; Corredoira, 2008; Martínez, 2019) and coniferous trees (Kim, 1999; Salajová, 2005; Maruyama, 2019), in addition to some shrubs (Shekhawat, 2016), ferns (Grzyb, 2019), crops (Gamborg, 1968; Hayta-Smedley, 2018) and 
medicines (Langhansová, 2004; Farooq, 2018; Sedaghati, 2019). The somatic embryogenesis technology of these species plays an important role in the establishment of plantation forest systems (Timmis, 1998) especially for coniferous trees whose somatic embryogenesis technology is sufficiently advanced.

Traditionally, C. camphora is generally cultivated via two seedlings or cuttings (Zou, 2009). Previous research on somatic embryogenesis in species of the Lauraceae family has been reported, including Ocotea porosa (Pelegrini, 2011, 2013; Quoirin, 2011), Persea americana Mill. (Pliego-Alfaro and Murashige, 1988; Sánchez-Romero et al., 2006), Laurus nobilis (Canhoto et al., 1999; Al et al., 2014), Cinnamomum pauciflorum (Kong, 2009), and Ocotea catharinensis (Catarina et al., 2004, 2005). Most reports focus on rapid propagation technology (Huang et al., 1998; Babu et al., 2003; Hemant et al., 2010), but few histocytological studies investigate somatic embryo regeneration. Among these, work by Du (2005), Du et al. (2006) obtained somatic embryos from immature zygotic embryos and protoplasts of the same $C$. camphora genotype via an embryogenic callus pathway. Shi (2009) published research on improving the secondary somatic embryo induction rate and reducing the browning rate, and Yang et al. (2018) studied the effects of hormones on somatic embryogenesis for different provenances in China of C. camphora.

In this study, we observed the key modes of $C$. camphora somatic embryogenesis at the morphological and cytological levels and explored in detail the occurrence and development of primary embryos and the characteristics of abnormal embryos. The histocytological examination of this species may be extremely useful for improving somatic embryo induction, maturation, and germination research as the internal structures of the plants are highly responsive to environmental modifications (Shekhawat, 2018).

\section{Materials and Methods}

\section{Sample preparation}

Donor Cinnamomum camphora seeds were collected from 20-year-old adult trees with a diameter of $24 \mathrm{~cm}$ at breast height, which were free of diseases and insect pests, at the Central South University of Forestry and Technology, in Changsha City, Hunan Province, China. In early July 2018, we randomly selected three mature $C$. camphora trees and randomly picked 50 green immature fruits from each tree. A total of 150 fruits were removed and then randomly mixed. Selected fruits with an approximate diameter of 0.6 $\mathrm{cm}$ were hand-picked and brought to the laboratory, where their peel and pulp were removed, and their fruits were collected and stored at $4{ }^{\circ} \mathrm{C}$ in refrigerators as research material.

Following Du et al. (2006) but with appropriate adjustments, immature zygotic embryos from the collected seeds were cultured in darkness on a culture medium M1 containing Murashige and Skoog (MS; 1962), $1.0 \mathrm{mg} \cdot \mathrm{L}^{-1}$ benzylaminopurine (BA), $0.1 \quad \mathrm{mg} \cdot \mathrm{L}^{-1} \quad 2,4$ dichlorophenoxyacetic acid (2,4-D), $6.5 \mathrm{~g} \cdot \mathrm{L}^{-1}$ agar, 700 $\mathrm{mg} \cdot \mathrm{L}^{-1}$ hydrolyzed casein and $30 \mathrm{~g} \cdot \mathrm{L}^{-1}$ sucrose. Putting them on an aseptic table for culturing and were subcultured onto fresh medium of the same composition every 15 days. After dark-culturing to produce the embryogenic calli, the embryogenic calli were transferred into a second culture medium M2 containing MS, $1.0 \mathrm{mg} \cdot \mathrm{L}^{-1} \mathrm{BA}, 1.0 \mathrm{mg} \cdot \mathrm{L}^{-1}$ naphthaleneacetic acid (NAA), $6.5 \mathrm{~g} \cdot \mathrm{L}^{-1}$ agar, $30 \mathrm{~g} \cdot \mathrm{L}^{-1}$ sucrose and $1000 \mathrm{mg} \cdot \mathrm{L}^{-1}$ malt extract. Putting M2 mediums under cool-white fluorescent light culture each day to stimulate somatic embryo induction. The embryogenic calli were repeatedly subcultured onto fresh medium of the same composition every $10 \mathrm{~d}$. After subcultured 3 times, the embryoid body matured on a hormone-free MS medium. Secondary somatic embryogenesis was initiated from primary somatic embryos. Two immature zygotic embryos were cultured on each medium during the experiment, for a total of 30 bottles. The $\mathrm{pH}$ of all media was adjusted to 5.8 before autoclaving. Plant hormone was added prior to the autoclaving of media, which was carried out for $25 \mathrm{~min}$ at $121{ }^{\circ} \mathrm{C}$ (Shi, 2008). The light culture consisted of $1500 \mathrm{~lx}$ light intensity for $12 \mathrm{~h}$ daily, whereas the dark culture was under darkness all day; both cultures were kept at a temperature of $25^{\circ} \mathrm{C}$ and a relative humidity of approximately $60 \%$.

To observe their histological and cytological features at various stages throughout the development of the primary somatic embryos and secondary somatic embryos, five $0.1 \mathrm{~g}$ samples were taken serially and randomly at a time, every 3 $\mathrm{d}$, for a 1-month-long period on a hormone-free MS medium until the embryogenic material of $C$. camphora in different development stages was obtained. The total of 50 samples included the non-embryogenic callus, embryogenic callus, and somatic embryos at distinctive developmental stages (i.e., globular embryo, heart-shaped embryo, torpedo embryo, and cotyledon embryo).

\section{Experimental methods}

NIKON digital cameras were first used to photograph the histological progress of somatic embryogenesis (Figs. 1$3,5)$. Sections were prepared using the conventional paraffin sectioning method (Liang, 2018). All materials were placed in formalin-glacial acetic acid-50\% ethanol (FAA 5:5:90, by volume) and stored overnight in a $4{ }^{\circ} \mathrm{C}$ refrigerator. Samples were then dehydrated in an ethanol series (50\%, 75\%, 85\%, 95\%, and 100\%), and infiltrated and embedded in paraffin wax (at 58-62taf over $12 \mathrm{~h}$ (Wang and $\mathrm{Li}, 2012$ ). Using the Leica rotary microtome, paraffin sections were cut with a thickness of $9 \mu \mathrm{m}$, dewaxing and dyeing the material with only $0.5 \%$ fast green was prepared with $95 \%$ alcohol for dyeing. Since these samples were very young, the cells lacked xylem. As a result, when the process lasted $7 \mathrm{~min}$, the excess fast green was washed out by $95 \%$ alcohol. Finally, neutral gum seals were used to seal the sections, and each prepared slide was positioned under the Zeiss microscope for observation and imaging.

\section{Data processing}

The explants after inoculation were observed daily to determine the somatic embryo induction proportion, browning proportion, and pollution proportion. We also observed morphological characteristics of the C. camphora callus after inoculation. The three proportion variables were calculated as follows: 
1350

Somatic embryo induction proportion $(\%)=$ (total number of zygotic embryos induced by somatic embryos/total number of zygotic embryos $) \times 100$

Browning proportion $(\%)=$ (number of browned zygotic embryos/total number of inoculated zygotic embryos) $\times 100$

Pollution proportion $(\%)=$ (number of contaminated zygotic embryos/total number of inoculated zygotic embryos) $\times 100$

\section{Results}

\section{Modes of occurrence}

Regeneration of $C$. camphora plants could occur via the somatic embryogenesis or organogenesis pathways. The former was further divided into two types. The first type was indirect production, in which zygote embryos dedifferentiated to produce a brown callus and then differentiated to form a transparent and pale-yellow somatic embryo (Fig. 1-A), which converted into a plant. The second type was direct generation, which could occur via two modes: (1) hypocotyl of the zygotic embryo directly induced the pale-yellow somatic cells, the germ end, and the radicle end, which took roots to produce regenerated plants (Fig. 1-B); and (2) cotyledon embryos were first induced at the hypocotyl of the zygotic embryos (Fig. 1-C), which turned into regenerated plants through tissue budding (Fig. $1-\mathrm{D})$.
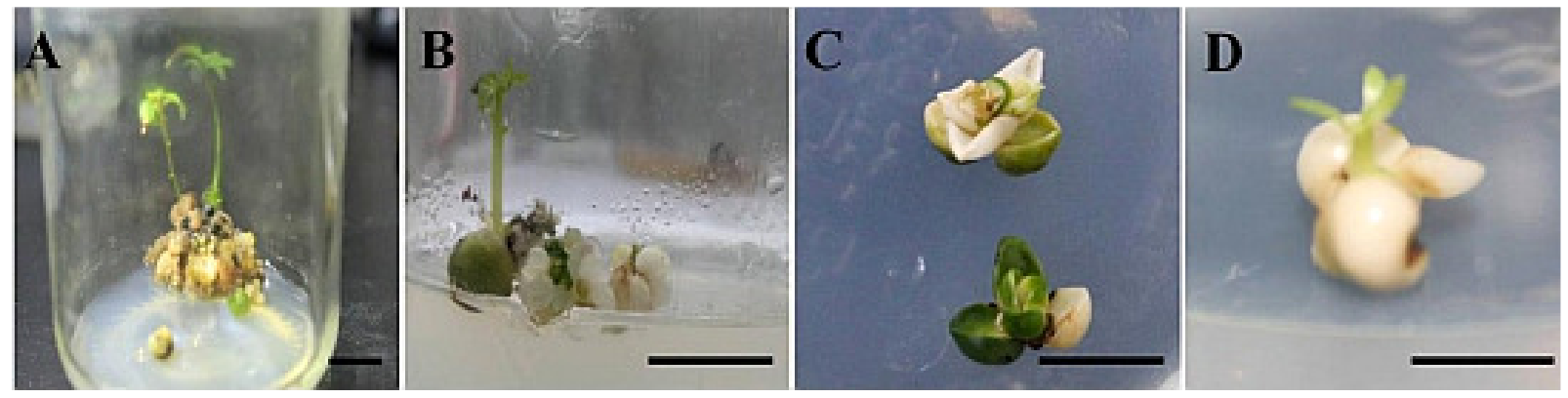

Fig. 1. The modes of somatic embryogenesis in Cinnamomum camphora. (A) indirect occurrence; (B) direct occurrence; (C) direct occurrence (germination); and (D) new plants formed by germination. Scale bar $=1 \mathrm{~cm}$

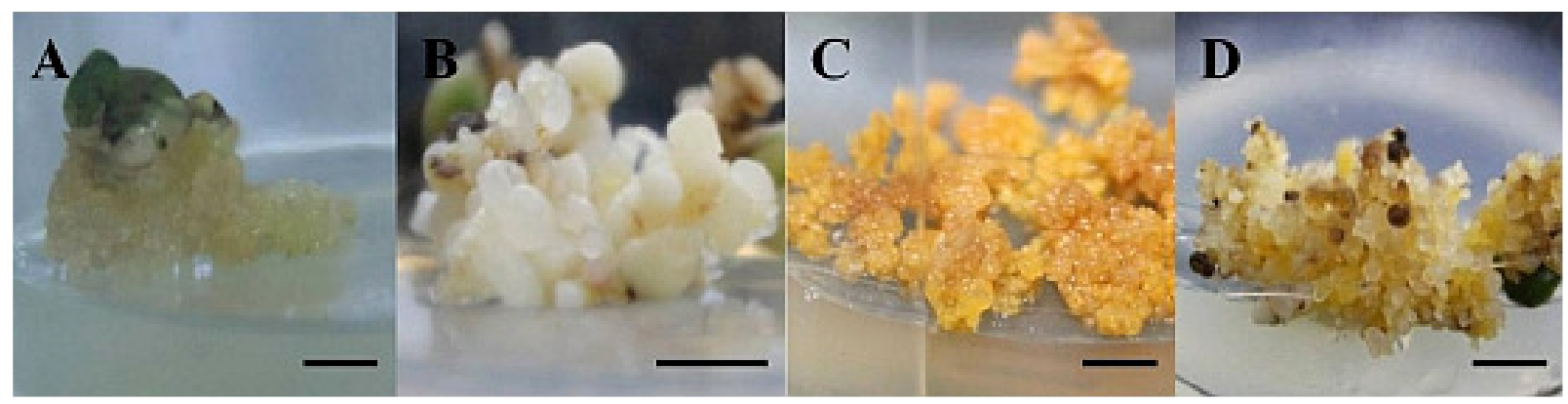

Fig. 2. Types of Cinnamomum camphora callus. (A) first kind of non-embryogenic callus; (B) second kind of non-embryogenic callus; (C) third kind of non-embryogenic callus; and (D) fourth kind of embryogenic callus. Scale bars $=0.5 \mathrm{~cm}(\mathrm{~A}, \mathrm{D}), 1 \mathrm{~cm}(\mathrm{~B}$, C) 

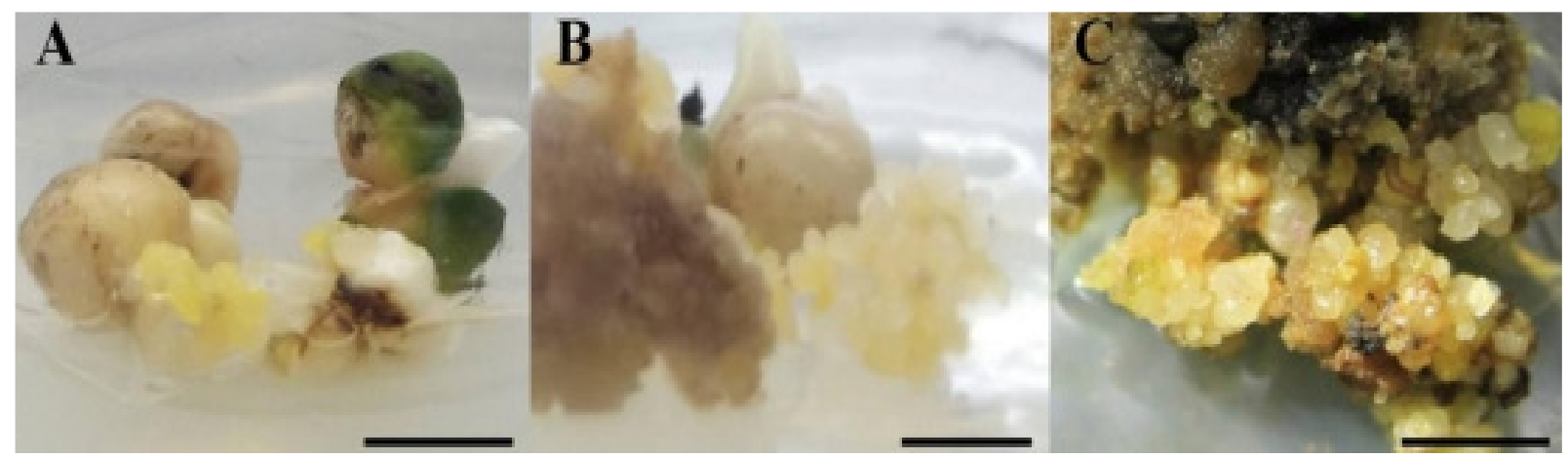

Fig. 3. Locations of the Cinnamomum camphora callus. (A) radicle tip; (B) exterior of non-embryogenic callus; and (C) exterior of browned non-embryogenic callus. Scale bars $=0.5 \mathrm{~cm}$

Table 1. Characteristic analysis of four types of Cinnamoumum camphora callus

\begin{tabular}{ccccc}
\hline Plant traits & 1st callus type & 2nd callus type & 3rd callus type & 4th callus type \\
\hline Cellular morphology & $\begin{array}{c}\text { Large volume, irregular shape, } \\
\text { thin wall, } \\
\text { less inclusions }\end{array}$ & $\begin{array}{c}\text { Large volume, ellipsoidal } \\
\text { shape, vacuolization }\end{array}$ & $\begin{array}{c}\text { Aging death, beginning to } \\
\text { disintegrate }\end{array}$ & $\begin{array}{c}\text { Small volume, round in shape, } \\
\text { thick cell wall, dense cytoplasm, } \\
\text { starch-based inclusions are } \\
\text { numerous }\end{array}$ \\
$\begin{array}{c}\text { Degree of } \\
\text { susceptibility to dyeing } \\
\text { Production time }\end{array}$ & After 12 days of inoculation \\
$\begin{array}{c}\text { Somatic embryo } \\
\text { induction rate }\end{array}$ & $0 \%$ & After 20 days of inoculation \\
Browning rate & $67 \%$ & $0 \%$ & After 50 days of inoculation & After 22 days of inoculation \\
\hline Note: more "+" symbols indicate a stronger effect & $13 \%$ & $0 \%$ & $73 \%$ \\
\hline
\end{tabular}

The third type of non-embryogenic calli (Fig. 2-C) consisted of 2-mm green and dark-yellow large granular dispersions. These tissues were brittle and loose, leaving the calli loosely connected to the explants and separable without external force. The growth rate of the calli granules was slow and the viability was low. After subculturing once or twice, browning death ensued, and somatic embryonic cells were not induced.

The fourth type of embryogenic calli (Fig. 2-D) consisted of 2-mm globular bulges. These cells were small in size and contained many intracellular substances. The whole calli were white, with light yellow granules scattered on their surfaces. Their growth rate was fast and therefore amenable to being subcultured many times.

After one month of culturing, the C. camphora embryogenic calli developed into white cotyledon embryos visible to the naked eyes. In terms of location, as shown in Fig. 3, the non-embryogenic calli first occurred in the middle of two cotyledons and expanded continuously to their outside. For the embryogenic calli, there were three discernable types: one type occurred at the radicle end, where most embryogenic calli formed by direct generation. Another type occurred on the exterior of the nonembryonic calli whose marginal cells formed embryonic cells through mitosis. The embryonic cells further divide and proliferate to form granular mass-like embryonic calli, located on the non-embryonic calli exterior. The third type is a more special case, in that very few non-embryogenic calli induced embryogenic calli at their exterior edges, which led to browning or fading after transferring several times.

Differences between embryogenic and non-embryogenic cells of C. camphora

Microscopic observation of the embryogenic calli revealed many differentiation centers. For example, the inner part harbored embryonic cells (Fig. 4-A black arrow and red arrow) while the outer part consisted of nonembryonic cells (Fig. 4-A blue arrow and yellow arrow) .

Embryonic cells were small, ca. 13-30 um in size, ellipsoidal, closely arranged, and easily stained. One type had dense cytoplasm, their nuclei were in the middle, a large content of starch granules (Fig. 4-B black arrow), and cells were mostly located at the edge of the differentiation center (Fig. 4-A black arrow). Another type's cell cytoplasm was also dense, but their nuclei were at the edge and they had a small content of starch granules (Fig. 4-B red arrow). These types of embryonic cells were generally found in the middle of the differentiation center (Fig. 4-A red arrow). The latter type of embryonic cells (Fig. 4-B red arrow) completed initial differentiation and would later develop into globular embryos.

In the periphery of differentiation center, we found the first type of non-embryonic cells. These cells hardly contained any starch granules (Fig. 4-C black arrow). The second type of non-embryonic cells, featuring a large vacuole-like volume (Fig. 4-C red arrow), and this type of cells surrounded the first type of non-embryonic cells. 
1352

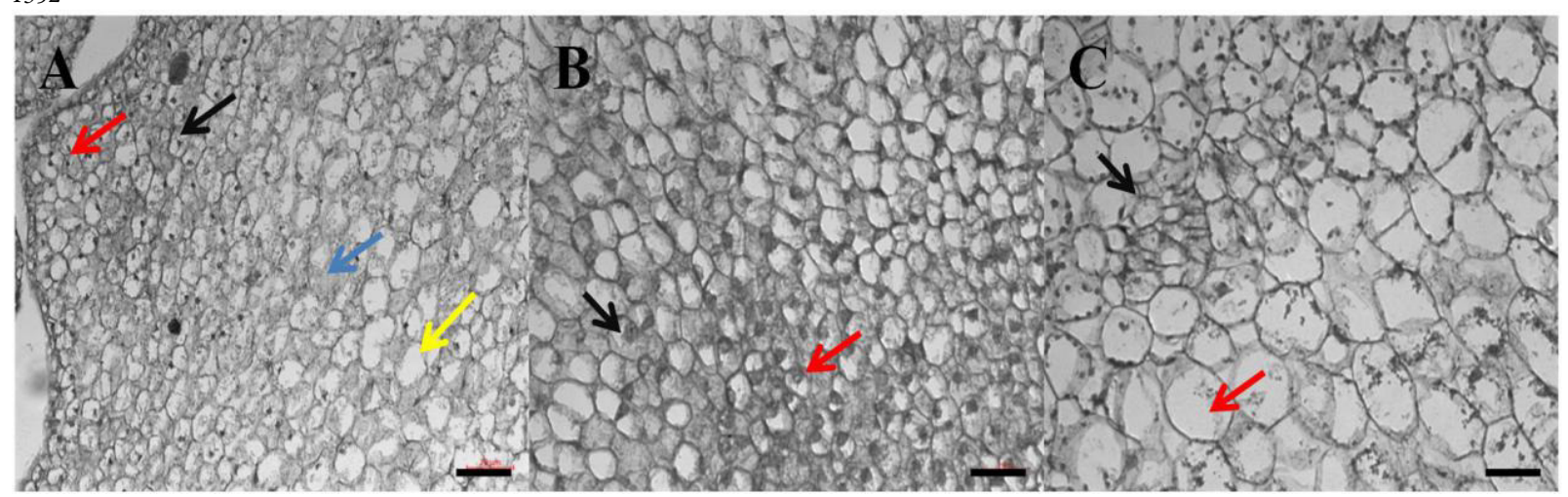

Fig. 4. Differences between embryonic and non-embryonic cells of Cinnamomum camphora. (A) Distribution of embryonic and non-embryonic cells. Red arrow represents the second type of embryonic cells and black arrow represents the first type of embryonic cells. Blue arrow represents the first type of non-embryonic cells and yellow arrow represents the second type of nonembryonic cells. (B) Embryogenic cell. Black arrows represent the first type of embryonic cells and red arrows represent the second type of embryonic cells. (C) Non-embryonic cell. Black arrows represent the first type of non-embryonic cells and red arrows represent the second type of non-embryonic cells. Scale bar $=20 \mu \mathrm{m}$

Histological process of somatic embryogenesis origins and development in C. camphora

After thirty days, many pale-yellow embryogenic calli formed. Approximately fourteen days later, the color of each embryogenic calli deepened into yellow, and many protrusions formed. Ten days later, these protrusions differentiated into globular embryos (Fig. 5-A) that subsequently developed into heart-shaped embryos (Fig. 5B), torpedo embryos (Fig. 5-C), and cotyledon embryos (Fig. 5-D).

Due to the asynchrony of somatic embryos, these four somatic embryos that correspond to different developmental stages could be observed simultaneously in embryogenic calli (Fig. 5-E), most of which were white and transparent, and easily separated from embryogenic calli surfaces after a period of growth. Additionally, some transitional embryoid shapes were occasionally observed; these were distinguishable as pear-shaped and rod-shaped embryos (as shown in Fig. 5-F).

When the cotyledon embryos' color changed from white translucent to white opaque, they were transferred to the differentiation medium. After fourteen days, the cotyledons turned green (Fig. 5-G), and the epicotyledons germinated and elongated and then grew the first pair of true leaves (Fig. 5-H). At the same time, the radicle germinated to complete plant morphogenesis (Fig. 5-I).

Secondary somatic embryos were also seen on the cotyledon and hypocotyl surfaces of cotyledon embryos. Although their germination patterns were similar to those of primary somatic embryos, they were more likely to produce malformed embryos consisting of two types: (1) a morphological malformation, such as conjoined embryos of the hypocotyl (Fig. 5-G) and radicle malformation (Fig. 5$\mathrm{K}$ ), and (2) there are two cotyledons in the embryoid body, but there are three or more cotyledons in the malformed embryos (Fig. 5-L).

Cytological process of origin and development of somatic embryogenesis in C. camphora

As shown in Fig. 6, somatic embryogenesis of $C$. camphora could arise from single cells (Fig. 6-I) or multicellular origins (Fig. 6-J), of which the former was dominant. This is characterized by the formation of two-cell proembryos, three-cell proembryos, four-cell proembryos (Fig.6-B), and multi-cell proembryos (Fig. 6-C) via singlecell (Fig.6-A) division, which then develops into four stages: globular (Fig. 6-D), heart-shaped (Fig.6-E), torpedo (Fig.6F), and cotyledon embryos (Fig. 6-G). The developmental processes of multicellular and single-cell origins were similar, with both passing through the four stages. Since somatic embryogenesis was asynchronistic, multiple stages could be seen simultaneously in one section slice. Below we describe the processes of single-cell and multicellular origins.

Single-cell origin of somatic embryos in C. camphora: as Fig. 6-A shows, single-cell blast cells were bulky, rich in starch grains, and mainly distributed around the nucleus. A small number of single-cell proembryos divided equally to form two-cell proembryos, and then divided once more to form three-cell proembryos or four-cell proembryos. Most single-cell proembryos divided unevenly along the short axis of the cell to form two cells differing in size; one was the spherical basal cell while the other was the apical cell and is often curved and knife-shaped (Fig. 6-B). Evidently, the apical cells divided into embryonic cells that were arranged tightly, i.e., round and small, with large nuclei, dense cytoplasm, rapid cell division and proliferation, and high starch content. After several transverse divisions, the basal cells formed multi-row suspensors. These suspensor cells were large, loose in arrangement, abundant in nutrients, and had inconspicuous nuclei. Multiple rows of suspensor cells could be seen in all four embryo stages (Fig. 6-K-6-L-6-M), and their late-stage degeneration was also evident. During somatic embryogenesis of C. camphora, rapidly dividing and proliferating embryonic cells were surrounded by thick walls, weakening the material exchange between somatic embryo cells and the callus, resulting in physiological isolation (Fig. 6-I). However, for differentiation of embryonic cell groups, a substantial amount of nutrients must be absorbed, which were transported and transmitted by suspensor cells to ensure normal differentiation. 


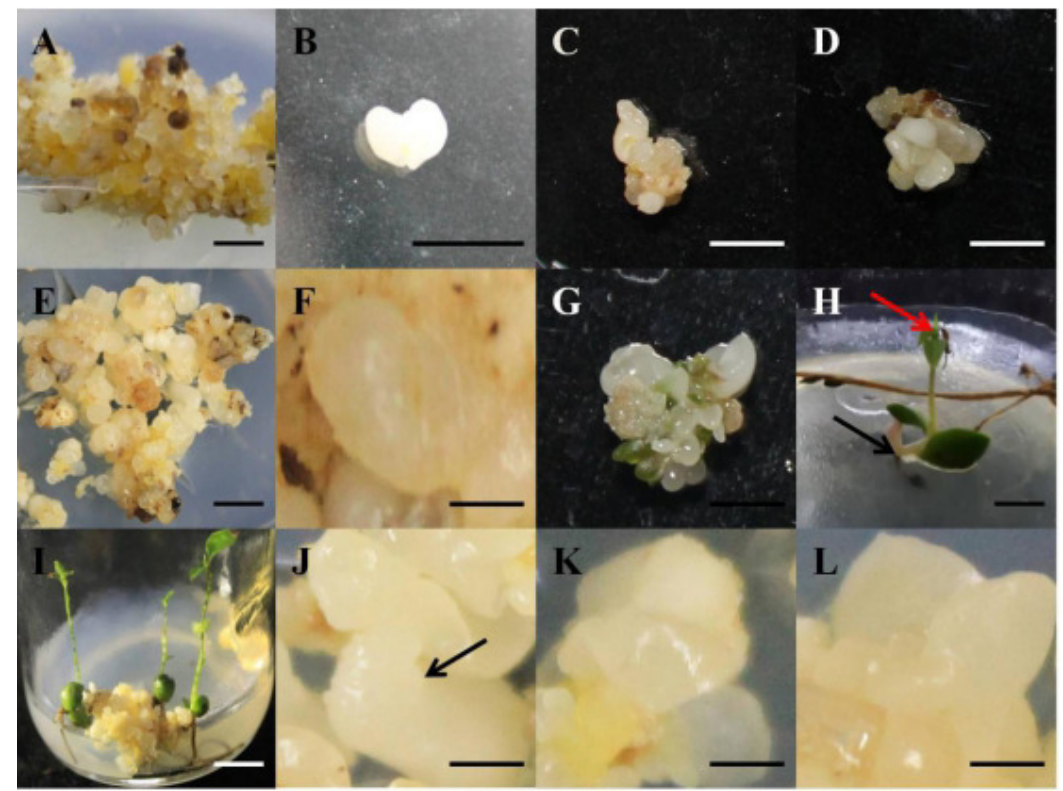

Fig. 5. Histological observations of somatic embryo development in Cinnamomum camphora. (A) globular embryo; (B) heartshaped embryo; (C) torpedo embryo; (D) cotyledonary embryo; (E) somatic embryos of different stages; (F) rod-like embryo; (G) germination of somatic embryo; $(\mathrm{H})$ bud and root of somatic embryo. Red arrow represents germ end and the black arrow represents the radicle end; (I) plantlet developed from somatic embryo; (J) hypocotyl malformed connecting embryos; (K) connecting embryos; and (L) malformed embryo of three cotyledons. Scale bar $=0.5 \mathrm{~cm}(\mathrm{~A}, \mathrm{E}, \mathrm{H}), 1 \mathrm{~cm}(\mathrm{I}), 1 \mathrm{~mm}(\mathrm{C}, \mathrm{B}, \mathrm{D}, \mathrm{F}, \mathrm{J}$, $\mathrm{K}, \mathrm{L})$, and $2 \mathrm{~mm}(\mathrm{G})$

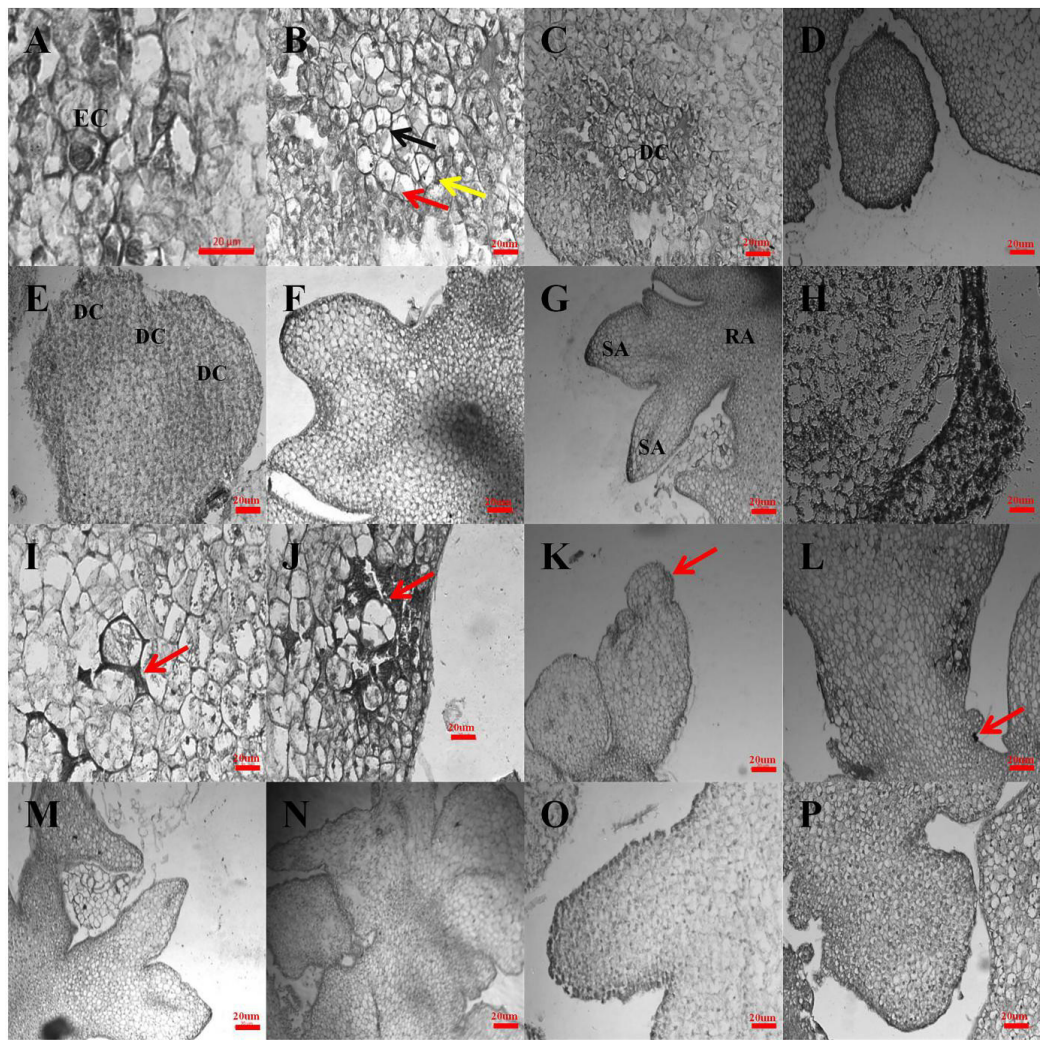

Fig. 6. Cytological observations of somatic embryogenesis sites in Cinnamomum camphora. (A)single-celled proembryo; (EC, embryonic cell); (B) two-celled proembryos, three-celled proembryos, and four-celled proembryos; yellow arrow represents the "T"-shaped three-celled proembryo, red arrow represents linear three-celled proembryo, and black arrow represents the "Tian"shaped four-celled proembryo; (C) multicellular proembryos (DC, differentiation center); (D) globular embryo; (E) heartshaped embryo; (DC, differentiation center); (F) torpedo embryo; (G) cotyledonary embryo; (SA, shoot apex; RA, root apex). $(\mathrm{H})$ radicle; (I) physiological isolation of single cells origin; (J) physiological isolation of multicellular cells origin; (K) secondary embryos formed on the surface of cotyledon embryos; (L) secondary embryo developed on the hypocotyls' poles of cotyledon embryo; (M) malformed embryo connected at radicle; (N) malformed embryo connected at radicle and hypocotyl; (O) rod-like embryo; and (P) multicellular embryos without obvious suspensors. Scale bar $=20 \mu \mathrm{m}$ 
1354

We identified three main modes of apical cell division (Fig. 6-B): (1) an apical cell longitudinal division and basal part co-constituted a "T"-type, three-cell proembryo; (2) an apical cell lateral division and basal part co-constituted a linear three-cell proembryo; and (3) simultaneously, both apical and basal cells divided longitudinally to form a "Tian"-type, four-cell proembryo. Each of these two-cell, three-cell, and four-cell proembryos had two polarities (i.e., radicle and germ poles) and in turn developed into multicellular proembryos. In the development of multicellular proembryos, the apical cell has an obvious vertical division, forming a circle of neatly arranged epidermal-like cell layers around it (Fig. 6-D) that separated the somatic embryos from the calli. Apical cells would continually divide into the pituitary and periphery, which was spherical at the head; at this moment, the globular embryo stage has begun.

Globular embryos that occurred on the surface and inside of the callus had symmetrical radiation. Their epidermal cells divided vertically to form 2 or 3 layers of primitive epidermis. When the diameter of the globular embryos reached ca. $150 \mu \mathrm{m}$, this primitive epidermis differentiated into epidermal layers (Fig. 7-A), and gradually detached themselves from the calli. While internal cells developed in multiple directions, those on both sides at the distal end of the suspensors divided faster in periclinal division than in vertical division. That is, as growth on both sides accelerated, two dividing centers formed (Fig. 6-D). The concave feature between these divisions centers corresponded to the apical meristem, in which procambium also began to develop. Early procambium cells were observed in the globular embryos, and dense vascular tissues were seen in the division centers. As the globular embryos developed into heart-shaped embryos, the cells in the heartshaped embryos shifted from radiation to bilateral symmetry, with three meristematic regions becoming evident (Fig. 6-E). Apical meristematic regions continuously divided downward, and on both sides they would develop into future cotyledons; these were possible as they formed early bud primordium in these regions and early root primordium at the suspensor end. At this time, the vascular tissues gradually extended downward, fusing a "V" shape in the centers of the heart-shaped embryos (Fig. 6-F) that continually developed. Then, somatic embryos developed into the torpedo embryo stage, where vascular tissues at both ends extended into the middle, and radicle division centers developed into root primordium. With hypocotyl elongation, the division centers and vascular tissues of the radicle are gradually formed, which eventually developed into the radicle (Fig. 6-H). In observing late cotyledons, we found that "Y-shaped" vascular bundles (Fig. 6-G) had formed which were the most prominent features of cotyledon somatic embryos, and also marked the successful completion of $C$. camphora somatic embryogenesis.

During the four stages of somatic embryos in $C$. camphora, the period of globular embryos and cotyledon embryos were relatively long (7-10 days) yet that of the heart-shaped or torpedo embryos was relatively short (3-5 days). Continuous sampling was necessary to more closely examine these two short periods. Nonetheless, transitional pear-shaped and rod-shaped embryos (Fig. 6-O), as well as malformed embryos (Fig. 6-M and 6-N), could be seen on the surface of the embryogenic calli.

After the primary somatic embryos matured, we discovered that secondary somatic embryos directly occurred on the surface of the primary somatic embryos' germ end and radicle end (Fig. 6-K, 6-L). Secondary somatic embryos were observed at all four stages of primary somatic embryos. The development process of the secondary somatic embryos was similar to that of the primary somatic embryos, and they could form their own vascular system and absorb nutrients by themselves.

The multicellular origin of $C$. camphora somatic cells occurred in two ways: (1) Cell clusters surrounded by sclerenchyma cells were found in the embryogenic calli. These multicellular proembryos underwent active pituitary and pericyclic division to form globular embryos, and the following processes were the same as described above. (2) The direct mode of occurrence included budding, which also had a multicellular origin, with no obvious suspensors during development (Fig. 6-P).

\section{Location and characteristics of somatic embryogenesis in $C$. camphora}

As shown in Fig. 7, the embryogenesis site of $C$. camphora somatic cells was primarily on the surface layers of the embryogenic calli; however, they occasionally occurred in their interior. Somatic embryonic cells originating from the surface layers of the embryogenic calli broke through their exfoliation during development (Fig. 7A-D). Globular embryos occurred within the embryogenic calli (Fig. 7-E), most gradually degenerating and dying during subsequent development. However, some developed into malformed embryos and few became cotyledon embryos that finally broke through the calli. However, unlike their surface occurrence, the cell debris present on the surface of the cotyledon embryos that had an internal origin were exfoliated from the calli (Fig. 7-F).

\section{Discussion}

Theories of somatic embryo origin and development process

Somatic embryogenesis occurs directly and indirectly (Zhang et al., 2007) in many woody plant tissue cultures. The same viewpoint has been put forwarded in studies of Liriodendron (Chen et al., 2003), Torreya grandis Fort. et Lindl. (Xiang et al., 2015) and Citrus reticulata Blanco (Long et al., 2017). Early research found that pre-embryonic determinant cells were present in directly occurring explants (Wang et al., 1993), and directly generating somatic embryos without the callus stage; this was in contrast to an indirect somatic embryogenesis system (Denchev et al., 1991). This indirect mode requires hormones to first induce pre-determinant cells, after which somatic embryo cells are grown (Williams and Maheswaran, 1986). During Cinnamomum camphora's somatic embryo development, we observed that few new plants could be directly generated. Therefore, to promote the induction rate of somatic embryos, we added appropriate hormones to the medium to produce many more embryogenic calli via an indirect occurrence mode. In the process of $C$. camphora somatic embryogenesis, a special direct method via-budding was also observed; their cotyledon embryos grew into regenerated 


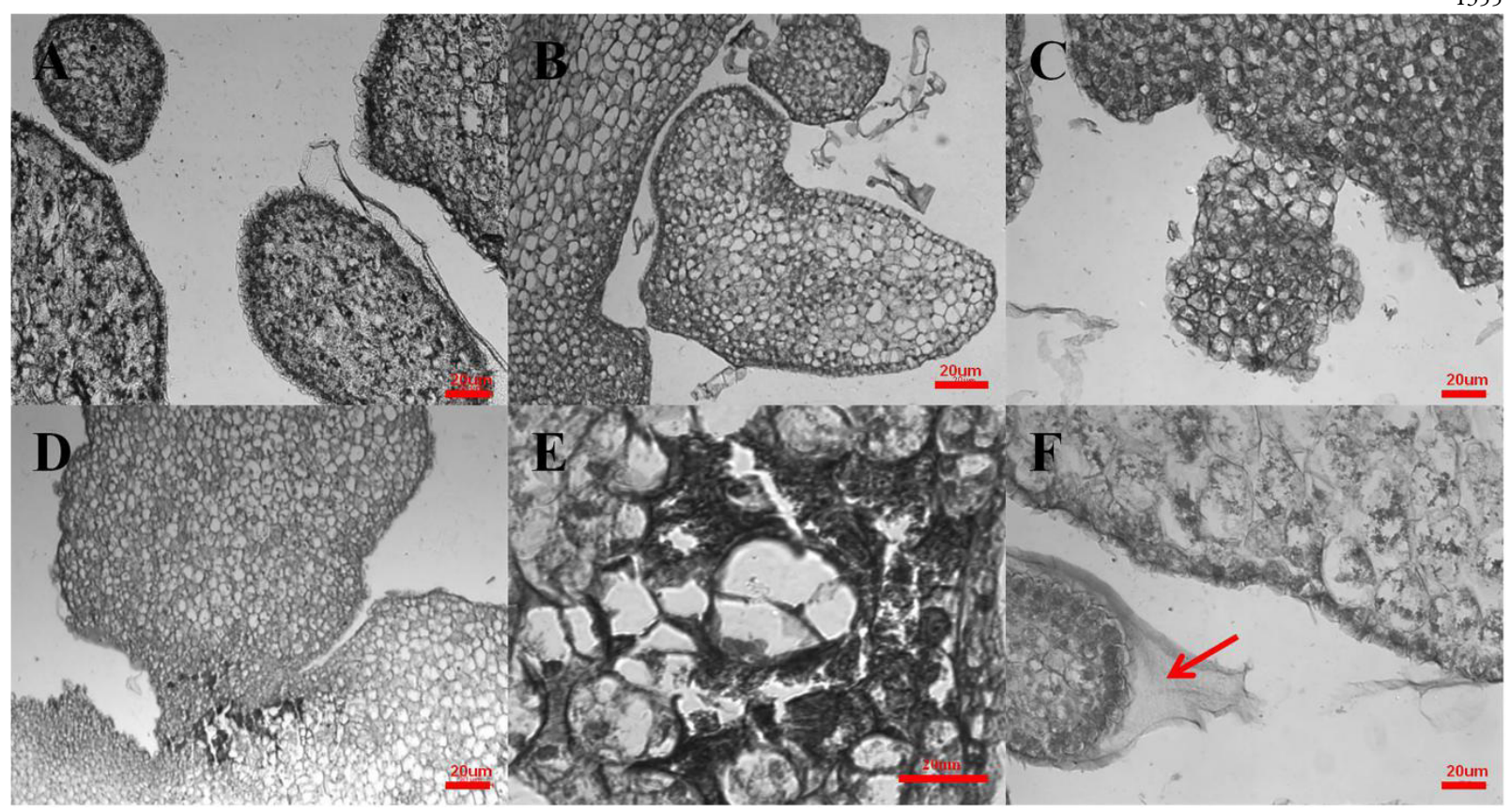

Fig. 7. Cytological observations of somatic embryogenesis sites in Cinnamomum camphora. (A) globular embryo falls off from the surface; (B) heart-shaped embryo falls off from the surface; (C) torpedo embryo falls off from the surface; (D) cotyledonary embryo falls off from the surface; (E) globular embryo in the callus; and (F) globular embryos breaking away from the callus. Red arrow points to cell debris. Scale bar $=20 \mu \mathrm{m}$

plantlets, which could normally root and germinate. However, the germination rates were low.

It has long been disputed whether plants originate from single cells or multiple cells (Alemanno et al., 1996). For example, Button and Botha (1975) found single cells in the Citrus reticulata Blanco callus and cultured them to produce somatic embryos, and thus inferring a single-cell origin. However, Steward et al. (1958) and others found small clusters of cells during suspension culturing of carrot plants (Daucus carota L. var. sativa Hoffm.) and cultured them to eventually produce somatic embryos, prompting these authors to believe the origin of development should be multicellular. In our study, somatic embryos of $C$. camphora had both single-cell and multi-cellular origins; however, it remains uncertain if the latter arose from single-cell proliferation. Hence, we need to further isolate and identify these contrasting origins in subsequent studies.

Currently, there are two leading theories to explain the formation of physiological isolation, that is, the cavity around proembryos. One explanation is that, as shown in celery plants (Kumar et al., 1980), multicellular proembryos are surrounded by a "marginal cell layer" that later disintegrates. Another way is to observe plants-as done for Lycium barbarum (Cui et al., 1997), Triticum aestivum (Cui et al., 1997), Onobrychis viciaefolia (Cui et al., 1997) and others-to find embryonic cells connected to surrounding cells by plasmodesmata. However, as embryonic cells develop, the plasmodesmata disappear or become clogged, resulting in sclerenchymal cells separating from surrounding cells. In our study, we observed that not only did the multi-primordial cell cluster have clear boundaries with surrounding cells, but that disintegration of sclerenchymal cells also occurred. Thus, our findings support Steward's (Steward et al., 1958) view that "physiological isolation between cells and surrounding tissues is the primary condition for embryogenesis". The premise of such "conditions" suggests that surrounding cells are relatively independent after somatic cell formation and are not yet completely blocked. As a result, somatic embryos may obtain nutrients from surrounding cells via suspensors (Guan et al., 2011) or rows of vessels (Xue, 2017).

The formation of vascular tissue in cotyledonary embryonic cells has also been reported in other woody plants. Such studies have shown that the formation of "Yor V"-shaped vascular bundles is a morphological hallmark of somatic embryogenesis (Hao et al., 1995), as demonstrated for Cnidium monnieri (L.) Cuss. (Hao et al., 1994), Liriodendron chinense tulipifera (Che et al., 2003), Torreya grandis Fort. et Lindl (Chen et al., 2012), and Saintpaulia ionantha Wendl (Zhang et al., 1982). Vascular tissue at the cotyledon stage is fully developed, including the cotyledons down to the radicle. In our study of C. camphora, the "Y"-type vascular bundle was clearly evident, thus indicating a matured cotyledonary embryo capable of absorbing nutrients on its own.

Similarities and differences between somatic and zygotic embryogenesis

Somatic embryogenesis of C. camphora is not unlike that of its zygotic embryogenesis (Schwendiman et al., 1988), as both apical and basal cells are formed at the initial stage of this plant's embryogenesis. All must transition through four stages to develop and mature, and they all featured physiological isolation phenomena. However, there are key 
1356

differences between them: (1) No fertilization occurs during somatic embryogenesis. (2) Somatic embryogenesis proceeds in direct and indirect ways, where the zygotic embryogenesis pathway is singular (Liu, 2013). (3) In somatic embryogenesis, not all basal cells will develop into suspensors. In some plant cells, suspensors are not obvious, and the layer numbers and arrangement of the suspensions are different. The suspensor cells are always present, especially in the late stage of differentiation when they may disintegrate. Du et al. (1997) observed that suspensor cells of somatic embryos disappeared earlier in somatic embryogenesis of Camellia sinensis var. assamica. (4) Developmental asynchrony is inherent to the process of somatic embryogenesis, whereas the corresponding stages of development in zygotic embryos are consistent (Liu, 2013). (5) The physiological isolation of somatic embryos and the isolation of zygotic embryos in the embryoid sac are different. Somatic embyros and calli are relatively independent during somatic embryogenesis, but other somatic embyros absorb nutrients from surrounding cells through their vascular system. (6) Somatic embryogenesis is more likely to produce abnormal embryos than zygotic embryogenesis.

\section{Causes of abnormal embryogenesis in somatic embryogenesis}

Through our paraffin-sectioned observations, some abnormal embryos were found to mainly have three types: conjoined abnormal embryos, cotyledon abnormal embryos, and morphological abnormal embryos. The formation of malformed embryos may occur due to the following reasons: (1) Hormones in the medium may have influenced cell development, especially our use of 2,4-D as it can lead to more malformed embryos (Hao et al., 1995). (2) Desynchronization of somatic embryos could have led to the production of malformed embryos (Chen et al., 2012). Other causes of abnormal embryogenesis have also been found in other works. For example, Benelli et al. (2000) thought that the failure of a number of secondary somatic embryos to develop into perfect structures could be ascribed to defects in the latter growth stages (i.e., fused embryos, fused cotyledons). Therefore, the formation of malformed embryos warrants further investigation, so as to control the formation of abnormal embryos from the root.

In the process of studying broad-leaved trees, there are often two pathways of occurrence: direct occurrence and indirect occurrence. In this study, detailed histocytological analysis was performed on the somatic embryogenesis process of Cinnamomum camphora. Based on the results of this experiment, we did not discover what causes the production of the two pathways, nor did we find the critical time points in the slice observations that influence both the direct and indirect pathways. In future research, we will compare the two pathways using alternative methods. For example, we can determine the differences in the contents of starch, soluble sugar and other influencing factors in the somatic embryos of the two pathways for the same period. In addition, we can apply the above-mentioned methods to other broad-leaved tree species, such as Liriodendron chinense, Catalpa bungei C.A. Meyer, and Cyclobalnopsis gilva, among others. By comparing the similarities and differences between the two occurrence pathways, the most critical influence points can be revealed, which can ultimately control the direction of artificial broad-leaved tree somatic embryogenesis.

\section{Conclusions}

In this paper, somatic embryogenesis of $C$. camphora was studied from five aspects: modes of occurrence, calli types and histocytological observations, differences between embryogenic and non-embryogenic cells, histological and cytological process of origin and development, and location and characteristics. This knowledge could assist in correctly controlling the time span from the previous to next stage medium, so that the embryoids could be transferred to the most suitable medium at the most appropriate time. Through this study, we can now better control the process of somatic embryogenesis, thereby obtaining higher induction and mature proportion of primary somatic embryos. At the same time, the transferred primary somatic embryos could be screened by cytological observation, which could effectively reduce the appearance of malformed embryos, thus ensuring they could grow normally and ultimately grow into robust plants. Our histological cytological study on somatic embryogenesis of C. camphora not only provides a new method for the rapid propagation of $C$. camphora, but also new ideas for somatic embryo technology for other tree species.

In future work, we plan to explore the influencing factors of direct and indirect occurrence, as well as identify whether the origin of $C$. camphora somatic embryo development is derived from single or multiple cells. Investigations on the nutrient absorption by suspensor cells and whether these will degenerate after formation should be conducted. By studying the somatic embryogenesis of $C$. camphora, we can gain a deeper understanding of its mechanisms and what controls the abnormal embryogenesis rate. This may be valuable for determining a robust somatic embryogenesis rate.

\section{Acknowledgements}

This research is supported by a Research Project from "13th Five-Year" National Key R\&D Program of China (grant no. 2016YFD06006005) and also the Program for Innovative Research Individual in University (grant no. 20183030). We thank all the teachers and classmates in our lab for constructive discussions and technical support.

\section{Conflict of Interest}

The authors declare that there are no conflicts of interest related to this article.

\section{References}

Al Gabbiesh AH, Ghabeish M, Kleinwächter M, Selmar D (2014). Plant regeneration through somatic embryogenesis from calli derived from leaf bases of Laurus nobilis L. (Lauraceae). Plant Tissue Culture and Biotechnology 24(2):213-221. 
Alemanno L, Berthouly M, Michaux-Ferrière N (1996). Histology of somatic embryogenesis from floral tissues cocoa. Plant Cell, Tissue and Organ Culture 46(3):187-194.

Babu KN, Sajina A, Minoo D, John CZ, Mini PM, Tushar KV (2003) Micropropagation of camphor tree (Cinnamomum camphora). Plant Cell, Tissue and Organ Culture 74(2):179-183.

Benelli C, Fabbri A, Grassi S, Lambardi M, Rugini E (2001). Histology of somatic embryogenesis in mature tissues of olive (Olea europaea L.). The Journal of Horticultural Science and Biotechnology 76(1):112-119.

Button J, Botha CEJ (1975). Enzymicmaceration of citrus callus and the regeneration of plant from single cells. Journal of Experimental Botany 26(5):723-729.

Canhoto JM, Lopes ML, Cruz GS (1999). Somatic embryogenesis induction in Bay Laurel (Laurus nobilis L.). In: Somatic embryogenesis in woody plants. Springer, Dordrecht pp 341-367.

Catarina C, Moser JR, Bouzon Z, Floh E, Maraschin M, Viana AM (2005). Protocol of somatic embryogenesis: Ocotea catharinensis Mez. (Lauraceae). In: Protocol for somatic embryogenesis in woody plants. Springer, Dordrecht pp $427-443$.

Catarina CS, Olmedo AD, Meyer GD, Macedo J, Amorim WD, Viana AM (2004). Repetitive somatic embryogenesis of Ocotea catharinensis Mez (Lauraceae): effect of somatic embryo developmental stage and dehydration. Plant Cell, Tissue and Organ Culture 78(1):55-62.

Chen J, Shi J, Zhu Q, Huang M (2003). Studies on the somatic embryogenesis of Liriodendron hybrids (L. chinese $\times$ L. tulipifera). ForestryScience 4:49-53.

Chen J,Zhang Y,Li T, Wang P, Wang G, ShiJ (2012), Study on origin and development of somatic embryos of Liriodendron hybrids. Journal of NanjingForestry University (Natural Science Edition) 36(1):16-20.

Cui K, WangJ, Xing G, Wang Y (1997). Ultrastructural and cytochemical localization of ATPase activity studies of embryonic cell differentiation in Lycium barbarum L. Journal of Northwest Botany 17(6):106-110.

Cui R, Fan T, Qu F, Zhai F, Liang L, Gong X (2008). Study on somatic embryogenesis of Cyclamen persicum Mill.Journal of Sichuan University (Natural Science Edition) 45(6):1477-1484.

Denchev P, Velcheva M, Atanassov A (1991). A new approach to direct somatic embryogenesis in Medicago. Plant Cell Reports 10(6-7):338341.

Du L (2005). Preliminary studies on plant regeneration via somatic embryogenesis and Agrobacterium-mediated transformation of campor tree (Cinnamomum camphora L.). Huazhong Agricultural University.

Du L, Ye Y, Bao M (2006). Study on somatic embryogenesis and plant regeneration of immature zygotic embryo of Cinnamomum camphora. ScientiaSilvae Sinicae 42(6):37-39 (in Chinese).

Du L, Zhou S, Bao M (2007). Effect of plant growth regulators on direct somatic embryogenesis in camphor tree (Cinnamomum camphora L.) from immature zygotic embryos and embryogenic calli induction. ForestryStudies in China 9(4):267-271.

Du K, Cao H, Zhang H, Zhao N, Li T (1997). Establishment of a system with high synchronous frequency of somatic embryogenesis and embryo seedling formation in Camellia sinensis var. assamica. Acta BotanicaSinica 39:1126-1130.
Grieve M (1979). A modern herbal. In: Leyel CF (Ed). A modern herbal. Jonathan Cape, Thirty Bedford Square,London pp 155-156.

Guan Z, Guo B, Wei Y (2011). Morphological and cytological observation of somatic embryogenesis and development in Lycopersivon esculentum Mill.Journal ofChinese Electron Microscopy Society 30(2):158-165.

Guo S, Geng Z, Zhang W, Liang J, Wang C, Deng Z, Du S (2016). The chemical composition of essential oils from Cinnamomum camphora and their insecticidal activity against the stored product pests. International Journal of Molecular Sciences 17(11):1836.

Häggman H, Vuosku J, Sarjala T, Jokela A, Niemi K (2006). Somatic embryogenesis of pine species: from functional genomics to plantation forestry. In: Somatic embryogenesis. Springer, Berlin, Heidelberg pp 119-140.

Hao J, Zhou X, Li B, Guo S, Chen R, Zhang J (1994). Observation on somatic embryogenesis in vitro culture of Cnidium monnieri young stem. Wuhan Botanical Research 3:247-250.

Hao J, Zhou X, Li S (1995). Morphological and cytological observation of somatic embryogenesis and development in Foeniculum vulgare. Journal of Experimental Biology 3:339-347.

Hayta-Smedley S, Özbek N, Ansiz A, Bayraktar M, Gurel A (2018). The effect of different plant growth regulators on callus induction from hypocotyl explants and plantlet regeneration through somatic embryo in cotton (Gossypium birsutum L.) genotype Nazilli-143. Anadolu Ege Tarımsal Araştırma Enstitüsü Dergisi 28(2):55-61.

Huang LC, Huang B, Murashige T (1998). A micropropagation protocol for Cinnamomum camphora. In Vitro Cellular and Developmental Biology-Plant 34(2):141-146.

Hemant S, Vashistha BD (2010). In vitro propagation of Cinnamomum camphora (L.) Nees \& Eberm using shoot tip explants. Annals of Biology 26(2):109-114.

Kong L, Dai D, Shang M, Li K, Zhang CX (2009). Thidiazuron-induced somatic embryos, their multiplication, maturation, and conversion in Cinnamomum pauciflorum Nees (Lauraceae). New Forests 38(2):131142.

Kumar PR, Tsunoda S (1980). Variation in oil content and fatty acid composition among seeds from Cruciferae. In: TsunodaS (Ed). Brassica crops and wild allies. Tokyo: Japan Scientific Societies Press pp 235-252.

Lattoo SK, Bamotra S, Dhar RS, Khan S, Dhar AK (2006). Rapid plant regeneration and analysis of genetic fidelity of in vitro derived plants of Chlorophytum arundinaceum Baker-an endangered medicinal herb. Plant Cell Reports 25(6):499-506.

LiangZ, Yuan C, Zhang B (2018). Experience in making paraffin sections of minute tissues. Chinese Journal of Histochemistry and Cytochemistry 4:368-373.

Lili S, Ying C, Nanyang W, Caiping X, Fuliang C (2012). Histological observation of somatic embryogenesis and adventitious buds induction from Ginkgo biloba L. different explants in vitro culture. Chinese Forestry Science and Technology 3:107.

Murashige T, Skoog F (1962). A revised medium for rapid growth and bioassays with tobacco tissue cultures. Physiologia Plantarum 15(3):473479.

Pelegrini LL, Ribas LLF, Amano E, Quoirin M (2013). Somatic 
1358

embryogenesis and morphoanatomy of Ocotea porosa somatic embryos. Ciência Florestal 23(4):595-605.

Pelegrini LL, Ribas LLF, Zanette F, Koehler HS (2011). Micropropagation of Ocotea porosa (Nees \& Martius) Barroso. African Journal of Biotechnology 10(9):1527-1523.

Pliego-Alfaro F, Murashige T (1988). Somatic embryogenesis in avocado (Persea americana Mill.) in vitro. Plant Cell, Tissue and Organ Culture 12(1):61-66.

Quoirin M, Pelegrini L, Ribas L (2011). Induction and repetitive embryogenesis of Ocotea porosa. In: BMC Proceedings 5(7):148.

Sánchez-Romero C, Márquez-Martín B, Pliego-Alfaro F (2006). Somatic and zygotic embryogenesis in avocado. In: Somatic embryogenesis. Springer,Berlin, Heidelbergpp 271-284.

Santa-Catarina C, Moser JR, Bouzon Z, Floh E, Maraschin M, Viana AM (2005). Protocol of somatic embryogenesis: Ocotea catharinensis Mez.(Lauraceae). In: Protocol for somatic embryogenesis in woody plants. Springer, Dordrecht pp $427-443$.

Schwendiman J, Pannetier C, Michaux-Ferrière N (1988). Histology of somatic embryogenesis from leaf explants of the oil palm Elaeis guineensis. Annals of Botany 62(1):43-52.

Shekhawat MS, Manokari M (2018). Micromorphological and anatomical evaluation of in vitro and field transferred plants of Coccinia indica. Agricultural Research 7(2):135-144.

Shi X, Dai X, Liu G, Zhang J, Ning G, Bao M (2010). Cyclic secondary somatic embryogenesis and efficient plant regeneration in camphor tree (Cinnamomum camphora L.). In Vitro Cellular and Developmental Biology-Plant 46(2):117-125.

Shi XP (2009). Enhancement of somatic embryogenesis and genetic transformation with Barnase and PaFT genes in Cinnamomum camphora L. PhD Dissertation, Huazhong Agricultural University, Wuhan, Hubei, China (in Chinese).

Steward FC, Mapes MO, Hears K (1958). Growth and organized development of cultured cells. II. Growth and division of freely suspended cells. American Journal of Botany 45(10):705-708.
Wang Y (2004). Histocytological study on somatic embryogenesis of Hevea brasiliensis. South China Tropical Agriculture University.

Wang Y, Cui K, Chen K, Gao Z, Zhang D, Jiao C (1993). Study on cytoembryology and starch growth and decline dynamics of somatic embryogenesis in Triticum acstivum tissue culture. Journal of Experimental Biology 3:259-267.

Williams EG, Maheswaran G (1986). Somatic embryogenesis: factors influencing coordinated behaviour of cells as an embryogenic group. Annals of Botany 57(4):443-462.

Xiang W, Zhao J, Wu J, Huang J, Yu W, Wu L, Zhang Q (2015). Morphological and cytological observation of somatic embryogenesis and development in Torreya grandis 'Merrillii'. Acta Horticulturae Sinica 42 (8):1477-1486.

Xinju Z (2009). Research overview on the breeding and cultivation of Cinnamomum camphora. Guangdong Forestry Science and Technology 2009-01.

Xue B (2017). Histological research of somatic embryo genesis and development in two Lily species native to China. Shenyang Agricultural University.

YangL, LiZ, Lin L (2018). Effects of hormon on the somatic embryogenesis from different provenances of Cinnamomum camphora. Journal of Central South Forestry University 38(12):115-120.

Zhang C, Yao Z, Zhao Z, Qi J (2007). Histological observation of somatic embryogenesis from cultured embryos of Quercus variabilis BI. Journal of Plant Physiology and Molecular Biology 33(1):33-38.

Zhang W (1982). Morphological study on embryogenesis in leaf culture of Saintpaulia ionantha Wendl. Acta Botanica Sinica 24(8):282-284.

Zou H, Yong K, Wang W (2009). Research progress on tissue culture and rapid propagation technology of Cinnamomum camphora L. Fujian Agricultural Science and Technology 1:71-72. 